\title{
現地実験による伝統的木造住宅の構造性能に関する研究
}

山口県の農家を対象とした静的水平加力実験

\section{STUDY ON THE STRUCTURAL PERFORMANCE OF TRADITIONAL TIMBER HOUSE BASED ON ON-SITE LOADING TEST \\ Lateral loading test of a farmhouse in Yamaguchi prefecture}

\author{
佐藤弘美*1, 松田昌洋*2, 藤田香織*3, 腰原幹雄*4, 坂本 功*5 \\ Hiromi SATO, Masahiro MATSUDA, Kaori FUJITA, \\ Mikio KOSHIHARA and Isao SAKAMOTO
}

\begin{abstract}
This paper presents the results of static lateral loading test performed on traditional timber farmhouse in Japan. The aim of this research is to clarify the horizontal load carrying capacity and the failure mode of this type of house by full scale experiment. As a result of the experiment, the maximum horizontal load was $45 \mathrm{kN}$ at the deformation angle $1 / 35 \mathrm{radian}$. Static analysis using a theoretical model considering the structural performance of joint and deterioration of timber was performed. The results of the analysis are discussed in comparison with those of the experiment.
\end{abstract}

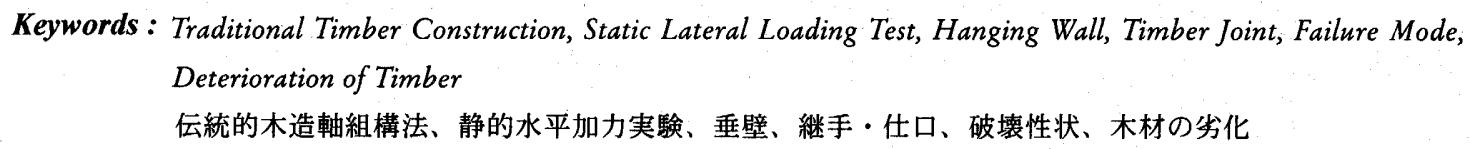

1. はじめに

\section{1 研究背景・目的}

伝統的木造住宅は、一般的な在来軸組構法を用いた木造建築とは 異なり、無開口壁が少なく垂壁を含む軸組に水平耐力が依存してい るものが多い。近年、伝統的木造住宅の保存や活用が活発化してい るが、一般的な構造計算における水平耐力要素は無開口壁のみとさ れていたために、開口部の多い伝統的木造住宅の構造性能の評価は 低く、保存・活用していくことが難しかった。しかし、2004 年に耐 震診断法 ${ }^{11}$ が改正され、垂壁などの伝統構法の部材も耐震要素とし て評価されるようになった。このことで伝統的木造住宅の評価が大 きく前進したが、各水平抵抗要素や住宅全体の性能の検証は未だ十 分であるとはいえない。また、災害時に古い伝統的木造住宅の被害 も認められたことから、実際に耐震性が不十分である伝統的木造住 宅も存在していると考えられ、それらの住宅については耐震性能を 高める必要性がある。伝統的木造住宅の持つ特性を現代に活かしな がら残していくために、その構造性能を検証し適切に評価すること は重要な課題である。本研究では以下の 3 点を目的として行った。 ・現地実験による伝統的木造住宅の大変形領域の復元力特性の把握 ・実大実験を用いた垂壁付き独立柱と柱接合部の力学モデルの検証 - 現地実験を踏まえた伝統的木造住宅の構造性能の解析的検証

\section{2 研究概要}

本稿では以下のような手順・方法で研究を行った。

1）伝統的木造住宅の構造性能を定量的に評価するために、現地での 静的水平加力実験を行った。2）対象住宅について力学モデルによる 解析を行い現地実験結果の評価を解析的に行った。3）解析の検証と して垂壁付き独立柱及び柱と横架材の接合部について実物大要素実 験を行い各要素の構造性能を把握した。4）3）の結果を基にした修 正力学モデルを用いて、伝統的木造住宅の構造性能の評価を行った。

\section{3 既往の研究}

伝統的木造住宅の構造性能を評価するために様々な研究が行われ

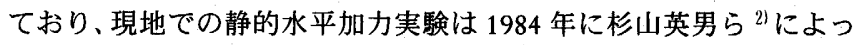
て行われたのをはじめとして各地で行われている ${ }^{31} \sim 11$ 。築 100 年前 後の伝統的木造住宅を対象として実験した事例が多い。建物が倒壊 するまで加力した事例は 2 棟であり、実験の多くは最大耐力を得た 時点及び加力装置の限界などで加力終了としていた。これらの既往 の研究では、住宅の持つ保有水平耐力や変形性状、大黒柱及び土壁 の水平耐力負担率などについて考察されている (2.4 章で詳述)。本 研究では倒壊もしくはそれに順ずる大変形領域での復元力特性の把 握之、対象住宅の材料実験や耐力要素の実大実験の結果を踏まえた 解析から、伝統的木造住宅の構造性能の評価を行った。
*1 首都大学東京大学院工学研究科建築学専攻 博士課程

*2 東京大学大学院工学系研究科建築学専攻 博士課程

*3 首都大学東京都市環境学部都市環境学科 准教授. 博士 (工学)

*4 東京大学生産技術研究所 助教授・博士 (工学)

*5 東京大学大学院工学系研究科建築学専攻 教授・工博
Graduate Student, Dept. of Arch., Graduate School of Eng., Tokyo Metropolitan Univ.

Graduate Student, Dept. of Arch., Graduate School of Eng., The Univ. of Tokyo Assoc. Prof., Dept. of Arch., Tokyo Metropolitan Univ., Dr. Eng.

Assoc. Prof., Institute of Industrial Science, The Univ. of Tokyo, Dr. Eng. Prof., Dept. of Arch., Graduate School of Eng., The Univ. of Tokyo, Dr. Eng. 


\section{2. 住宅の静的水平加力実験}

伝統的木造住宅の構造性能を定量的に明らかにするために、現地 での住宅の静的水平加力実験を行った ${ }^{12)}$ 。実験は農家型の伝統的木 造住宅を対象として行った。

\section{1 実験概要}

実験期間：2004 年 8 月～2004 年 9 月

実験内容 : (1)常時微動測定-自由振動実験 (2)静的水平加力実験（小 変形・大変形）(3)材料実験（柱・土壁）

実験対象 : 山口県山口市陶にある江戸末期に移築された農家を対象 とした（写真 1)。規模は $112.5 \mathrm{~m}^{2}$ （敷地北西部にあった堌築部分を 除く）であり、平入り・くい違い四間取り形式の住宅であった。架 構形式は双首組＋棟束であり（図 1)、柱の断面寸法、樹種、仕口に 用いられていた構法については表 1 に示す。地梁の配置は土間の各 方向に認められた。屋根形状は寄棟、麦菜惪・トタン張（下屋部分 は瓦惪）であった。壁の仕様は、外壁の一部に荒壁仕上げが認めら れたが、概ね㴚喰仕上げの土壁（厚さ約 $75 \mathrm{~mm}$ ）であった。平面形 式・間取りの特徵は、18 19 世紀前半の山口県の一般的な農家の特 徵であり ${ }^{13)}$ 、地梁の配置は東関東·中国山地で 17 世紀から認めら机

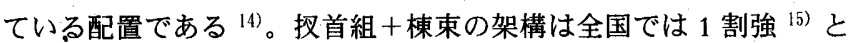

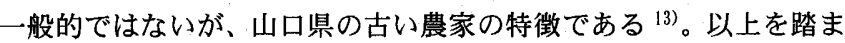
え、本住宅は山口県の一般的な農家型の伝統的木造住宅である。

建物の状態は、柱脚や柱頭、垂壁部分に蟻害・雨漏り等による劣 化が認められた（図 2）。特にX3Y2（図 2c）は、柱両側面に補強材 を設け、ボルトで他の部材と固定していた。

解体時に測定した部材寸法より、木部（アカマツ）の比重 0.59、 土壁の単位重量 $76.6 \mathrm{~kg} / \mathrm{m}^{2}$ として建物重量を算出したところ、建物 総重量は $255 \mathrm{kN}$ であり、柱下部を除いた重量は $228 \mathrm{kN}$ であった。 現行基準である建築基淮法施行令第 46 条に基づいて壁量計算を行 つたところ、有効壁長は梁間方向 $22.67 \mathrm{~m}$ 、㮏行方向 $12.25 \mathrm{~m}$ であっ た。必要壁長は梁間方向 $24.15 \mathrm{~m}$ 、析行方向 $16.88 \mathrm{~m}$ であり、両方向 とも満たしていない。なお土壁の壁倍率は告示第 1543 号より求めた。

\section{2 常時微動測定・自由振動実験}

本住宅の振動特性を把握するために、常時微動測定 (加力実験前 特定変形角時）と人力加振による自由振動実験（加力実験前）を行 った。サンプリング周波数は $200 \mathrm{~Hz}$ とし、常時微動測定は 5 分間、 自由振動実験は 1 分間の計測を行った。自由振動実験は、成人 2 名 が常時微動測定から得た固有振動数を基に建物を共振状態にし、加 振を止め建物を自由振動状態とした。計測にはサーボ型速度計 VSE-15D を 6 台と SPC-51（共に東京測振）を用いて、平面方向と 高さ方向の振動特性の把握を行った（図 3)。

\section{1) 固有振動数}

常時微動測定と自由振動実験の結果を基に FFT 解析を行い、伝達 関数を求めた（図 4)。最大振幅は表 2 に示すとおりである。加力実 験前の固有振動数は梁間方向で並進 $3.91 \mathrm{~Hz} 、 2$ 次 $8.59 \mathrm{~Hz}$ に、桁行 方向では並進 $3.52 \mathrm{~Hz} 、 2$ 次 $9.38 \mathrm{~Hz}$ 付近にピークが確認できた。妳 行方向ピーク時のモード図を図 5 に示す。自由振動実験では梁間方 向 $3.71 \mathrm{~Hz}$ 、桁行方向 $3.52 \mathrm{~Hz}$ 付近にピークが認められた。

\section{2) 減衰定数}

時刻歴の自由振動波形を基に対数減衰率から減衰定数を求めた。 その結果減衰定数は梁間方向 $2.6 \%$ 、桁行方向 $2.9 \%$ であった(表 2 )。
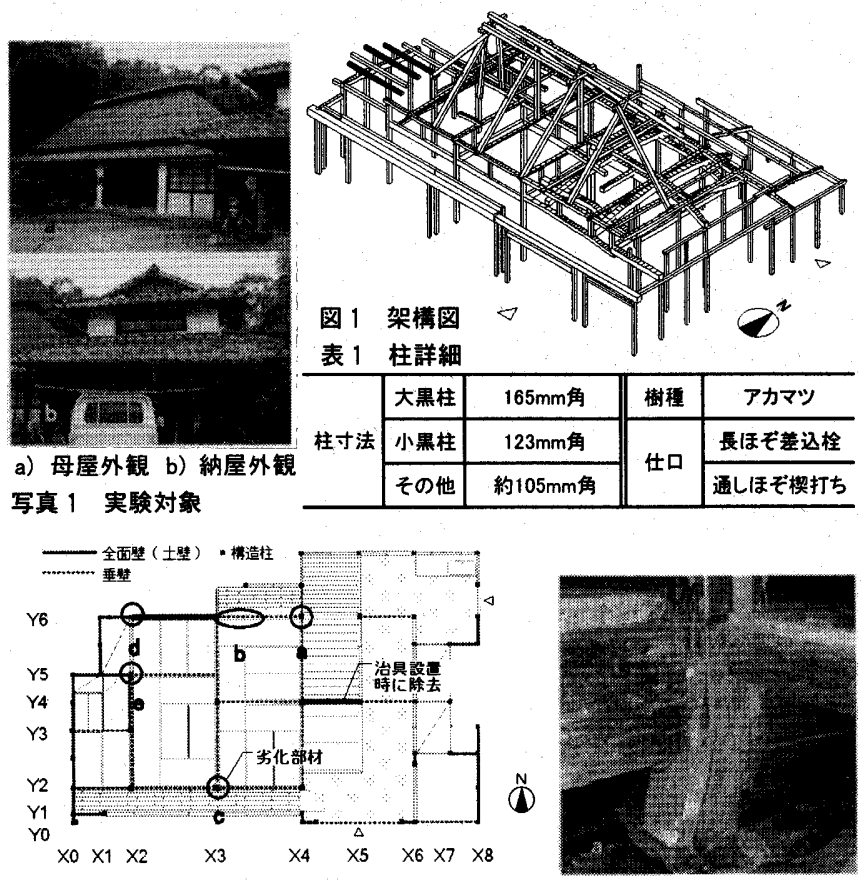

\section{a) 柱脚の損鹪 \\ b) 雨漏りによる} 垂壁の劣化

c）蟻害にあった 柱と補強材

d) 柱仕口の劣化

e) 柱脚の劣化
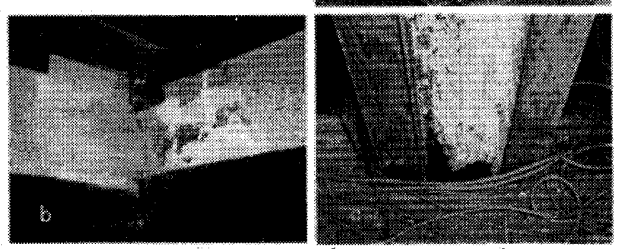

\section{図 2 部材の劣化状態}

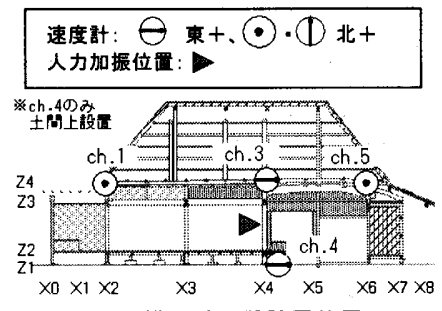

a) $Y 4$ 㭗面計測器設贯位置

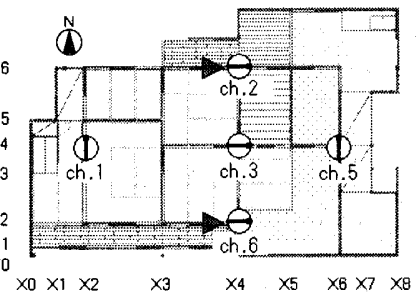

b) Z4レベル計測器設置位置
図 3 常時微動 測定計画例

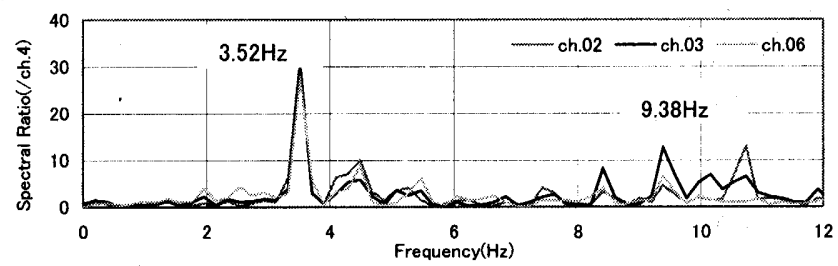

图 4 常時微動測定結果から求め太伝達関数（桁行 図 3 配置時）

表 2 振動特性

\begin{tabular}{|c|c|c|c|c|c|c|}
\hline \multirow{2}{*}{ 方向 } & \multirow{2}{*}{ 測定項目 } & \multirow{2}{*}{$\begin{array}{c}\text { 最大振幅 } \\
(\mathrm{mm})\end{array}$} & \multicolumn{3}{|c|}{ 固有振動数 $(\mathrm{Hz})$} & \multirow{2}{*}{$\begin{array}{c}\text { 減衰定数 } \\
(\%)\end{array}$} \\
\hline & & & 並進 & 2次 & 平面㟫れ & \\
\hline \multirow{2}{*}{ 梁間 } & 常時徽動 & 0.030 & 3.91 & 8.59 & 6.83 & - \\
\hline & 自由振䵢 & 0.197 & 3.71 & - & - & 2.6 \\
\hline \multirow{2}{*}{ 析行 } & 常時徽動 & 0.015 & 3.52 & 9.38 & 6.64 & - \\
\hline & 自由振動 & 0.282 & 3.52 & - & - & 2.9 \\
\hline
\end{tabular}
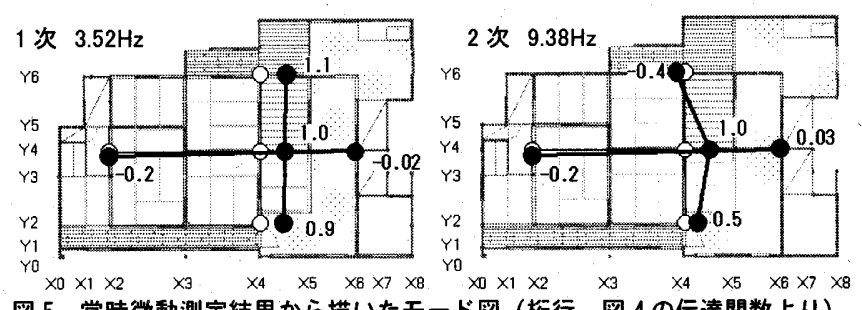


\section{3 静的水平加力実験}

析行方向に静的水平加力を行った（図 6、7)。桁高さに設置した ワイヤーを析両端の治具で固定し、建物全体に力がかかるよう加力 を行った。治具設置方法は図 8 に示す。反力には実験対象である母 屋に隣接していた納屋を補強して用いた。1 構面ずつ小変形させる 小変形加力を行った後に、主要な 3 構面を等変位に加力する大変形 加力を行った。本稿では大変形加力について詳述する。なお、加力 時には劣化部材に用いられていた角材やボルト等の補強材を取り外 し、更に増築部分と縁を切り離した状態とした。加力構面の部材を 中心に、変位計とひずみゲージを合計 $109 \mathrm{ch}$.設置して計測を行った。

\section{1）荷重一変形関係}

実験結果より $1 / 35 \mathrm{rad}$.時（小変形加力による残留変位を含めると $1 / 31 \mathrm{rad}$.時）に最大耐力 $45 \mathrm{kN}$ を得た（図 9)。剛性は約 $1 / 200 \mathrm{rad}$.以 降徐々に低下した。耐力はほとんど低下せず変形のみ進行する傾向 が認められた。復元力特性について詳細に分析を行うため、一度目 の載荷と除荷後の二度目の載荷について割線剛性を算出した。残留 変形を除いて比較した結果、0.01 rad.までの剛性約 $3500 \mathrm{kN} / \mathrm{rad}$. 0.01 rad.から 0.03 rad.までの岡性約 400 kN/rad.という值が得られ、ど ちらの載荷についても最大䨛力までに急激な剛性低下が認められた。

また、大変形加力直前に行った常時微動測定の結果から得られた 固有振動数 $3.0 \mathrm{~Hz}^{12}$ ) 基に微小変形（0.0001 rad.）時の剛性を算出 したところ約 $400000 \mathrm{kN} / \mathrm{rad}$.であった。実駼結果における初期剛性 より高い值を示した (図 9 参照)。なお、常時微動測定等の結果から 剛性を算出するには以下の式を用いた ${ }^{16)}$ 。

$k=(2 \pi f)^{2} \cdot m(k$ : 剛性 $f:$ : 固有振動数 $m:$ 建物質量 $)$

\section{2）変形性状}

実験後の建物の状態を写真 3 に示す。加力構面 Y6 の治具設置位 置（柱頭）等に劣化やほぞ穴跡に起因する破壊が認められたが、加 力による垂壁下端の柱の折損は認められなかった。最大耐力時まで は垂壁下で大きく曲げ変形した柱と、層全体がせん断変形した例が 観測された（図 10a,b)。最大耐力時以降は、柱の変形がさらに進行 し、漆喰の剥離や一部の壁の剥落、部材の引き抜き等が観測された。

垂壁付き独立柱の変形性状について詳細に考察する。前述のよう に 2 種類の変形性状が確認された。柱の断面寸法や垂壁高さによる 違いには有意な差は認められなかった。その他の要因を考えると、 曲げ変形を生じている垂壁付き独立柱には直交方向の垂壁を持つも のが認められた。せん断変形を起こしたものは直交方向の垂壁がな い箇所であった。また、垂壁下の鴨居せいが小さいものもせん断変 形が顕著であった。以上を踏まえ、垂壁付き独立柱の変形性状には、 上記 2 点の要素が影響しているのではないかと考える。

3) 応力

大黒柱と小黒柱からなる Y4 構面の部材応力を測定した。加力方 向の柱側面にひずみゲージを設置し、柱にかかるひずみ度を測定し た（図 11 拡大図)。測定したひずみから部材にかかる曲げモ一メン 卜を求め、せん断力を算出した ${ }^{17)}$ 。なお、曲げモーメント算出に用 いた柱のヤング係数は 2.5 章で後述する材料実験の結果を基に算出 した值（表 5）から $812.0 \mathrm{kN} / \mathrm{cm}^{2}$ とした。

最大耐力時には大黒柱が全体のせん断力の $5 \%(2.2 \mathrm{kN})$ 、小黒柱 が $3 \%$ （1.4kN）を負担しており、最大変形時には大黒柱が $7 \%$ $(3.3 \mathrm{kN}) 、 小$ 黒柱が $4 \%$ （2.0kN）を負担していた（図 $11 ） 。$

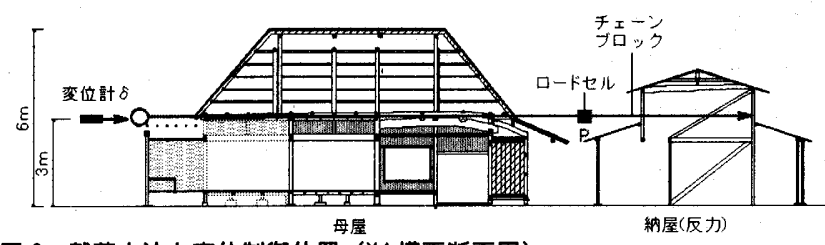

図 6 戴荷方法と変位制御位量（Y4 構面断面図）

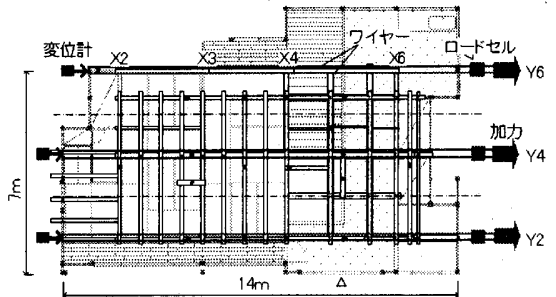

図 7 载荷方法と変位制御位置 (小屋伏图)

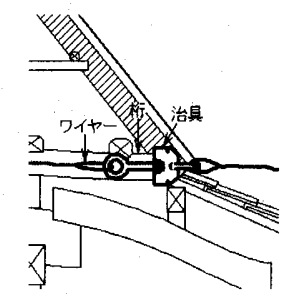

図 8 治具設置詳細図 固有周期から算出

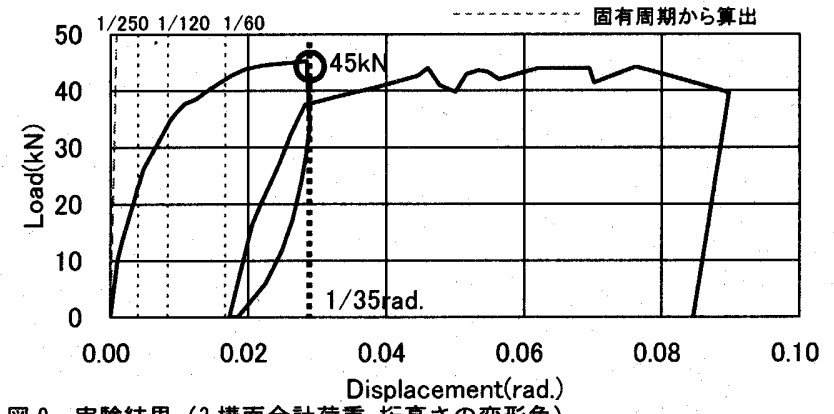

図 9 実験結果（3 構面合計荷重-桁高さの変形角）

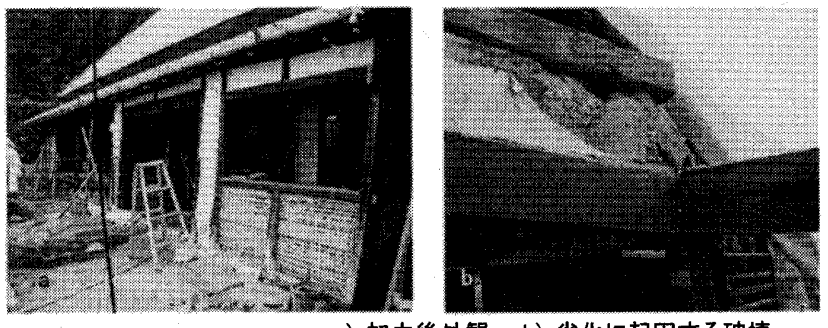

写真 3 実験後の様子

$$
\text { a）加力後外観 b）劣化に起因する破壊 }
$$
a) 柱の曲げ変形
b) 層全体の せん断変形
c）垂壁漆喰のはらみ
d）差鴨居の引き抜き
e) 柱の変形性状

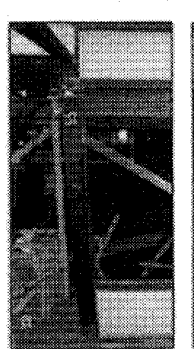

図 10 垂壁付き独立柱の変形性状
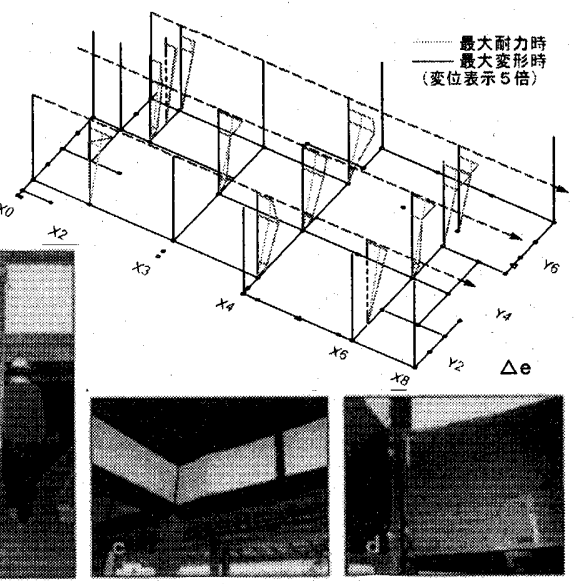


\section{4 既往の研究との比較}

本住宅の構造性能について詳細に検証するために、建物の特徵や 振動特性、最大耐力について既往の研究 2) 11) と比較を行った(表 3)。 1) 建物の特徽

平面形式は田の字型四間取り、〈い違い四間取り形式の農家型の

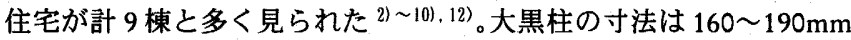
角、その他の柱は 115 155mm 角であった。本住宅の柱の断面寸法 は他の住宅と比較して 2〜3 割小さい。平面規模は 100〜200 $\mathrm{m}^{2}$ であ り、建物重量は $2.30 \mathrm{kN} / \mathrm{m}^{2}$ 前後の傾向が認められた。本住宅は柱な どの部材寸法が小さく、単位床面積あたりの重量は $2.03 \mathrm{kN} / \mathrm{m}^{2}$ であ り既往の研究の対象住宅と比較して軽いといえる。

\section{2）振動特性}

固有振動数は $1.7 \sim 3.9 \mathrm{~Hz}$ に分布している。建物の規模（床面積、 重量）との相関では、規模が大きいほど固有振動数は低下する傾向 が認められた。本住宅は重量が比較的軽く、固有振動数は各方向と も他の住宅の 1.2 2 倍程度大きかった。本住宅の減衰定数は 2.6〜 $2.9 \%$ であり、他の住宅と比較して明確な傾向は認められなかった。

\section{3）最大耐力}

加力方法等の点から破壊前に加力終了とした事例もあるが、実験 時の最大耐力は 44〜 $110 \mathrm{kN}$ と住宅によって差が認められた。本住宅 の最大耐力は $45 \mathrm{kN}$ であり、他の住宅の平均値より約 3 割低い。本 住宅の建物重量（柱下部を除く）は $228 \mathrm{kN}$ であることから、層せん 断力係数は 0.20 である。層せん断力係数で比較を行うと他の住宅の 実験結果は概ね 0.20 前後であり、本住宅の耐力は他の住宅と比較し て同等であるといえる。実験時の最大耐力を得た変形角は $1 / 30 \mathrm{rad}$. 前後が多く、本住宅も $1 / 35 \mathrm{rad}$.時に最大耐力を得た。1/20〜1/10 rad. で最大耐力を得る勒性の高い住宅も認められた 101 ，11)。

\section{5 材料実験}

本住宅の部材の構造特性を把握するため、住宅解体時に柱と土壁 からサンプルを切り出し（図 12）、要素実験を行った。

\section{1）木材の要素実験}

実験概要 : 柱のサンプル 6 体から $30 \mathrm{~mm} \times 30 \mathrm{~mm} \times 480 \mathrm{~mm}$ の試験体 （辺材、木取りは概ね柾目・追柾）を各 3 体作成し曲げ実験を行っ た。実験方法は、試験体両端をローラー支持とし試験体中央に加力 を行った（図 13）。計測には変位計、ひずみゲージ合計 6ch.用いた。 実験結果：最大耐力は 0.4 3.1kN であり、比例限度荷重は最大荷重 の $1 / 2 \sim 2 / 3$ 程度であった。X3Y4 とX3Y6 の各試験体では脆性的な 破壊は生じなかったが（図 14）、上記以外の試験体では最大霜力を 示した後急激に耐力が低下した。実験結果を基に曲げヤング係数、 曲げ比例限度、曲げ強度を算出した（表 4)。特に劣化の著しかった X4Y2 では他の試験体の値の 1/3 1/5 程度の値となった。

\section{2）土壁の要素実験}

実験概要 : 本住宅の一般的な土壁のサンプルを $260 \mathrm{~mm} \times 260 \mathrm{~mm}$ (厚 さ $74 \mathrm{~mm}$ ）の試験体 1 体に整形しせん断実験を行った（図 15）。実 験方法は、各辺をピン接合とした治具を用いて試験体対角線方向に 加力を行った。計測には変位計、ひずみゲージを合計 $56 \mathrm{ch}$.用いた。 実験結果 : 最大耐力は $3.63 \mathrm{kN}$ (せん断変形角 $0.042 \mathrm{rad}$.時) であっ た。最大耐力時に漆喰が剥落し、それ以降耐力が低下した。要素実 験に用いた土壁のせん断強度を実験結果から求めたところ約 $0.14 \mathrm{~N} / \mathrm{mm}^{2}$ であった（図 16）。実験の様子を写真 5 に示す。
表 3 既往の実験概要・実験結果との比較 ${ }^{2 ! ~ 12 ~}$

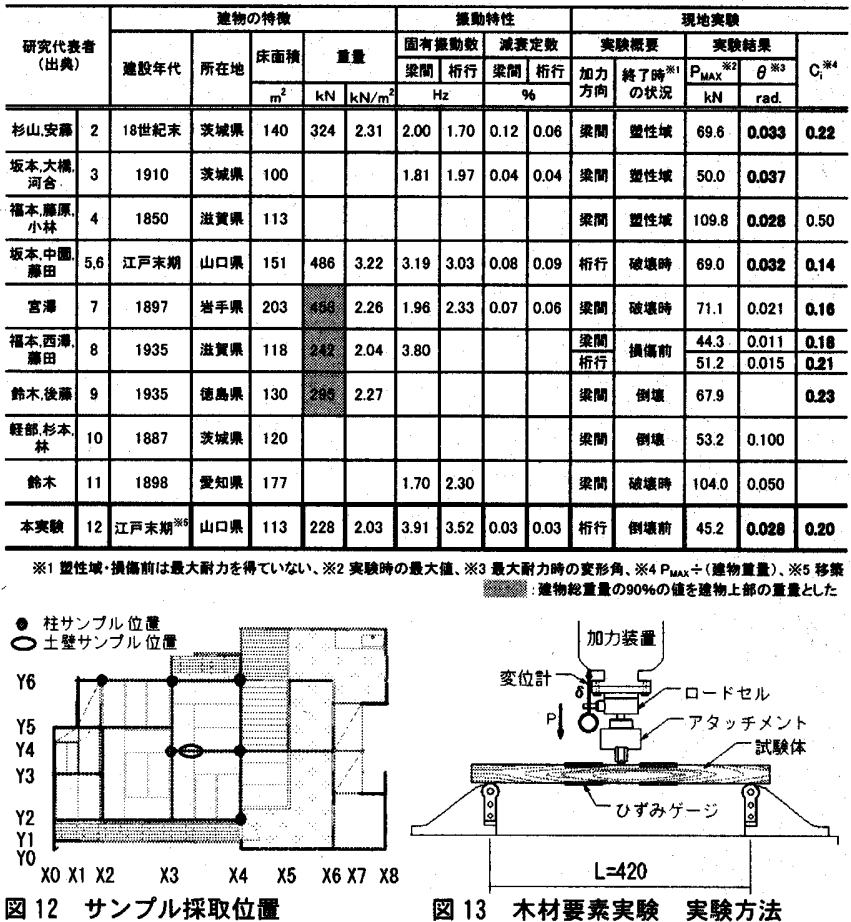

图 12 サンプル婹取位虽

图 13 木材要素実験 実験方法

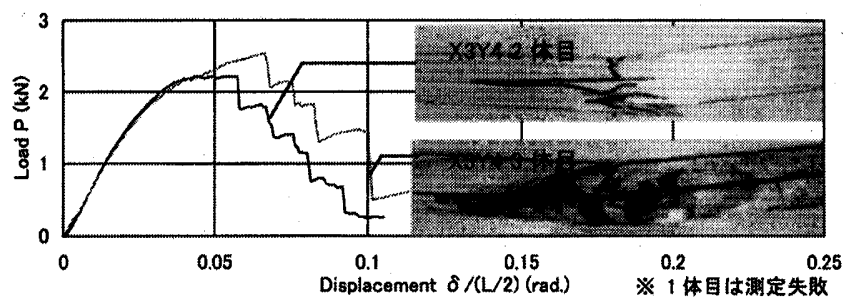

図 14 木材要素実験結果 例 X3Y4 荷重一変形関係と破壊性状

表 4 木材要素实験 実験結果

\begin{tabular}{|c|c|c|c|c|}
\hline 試硢体名 & $\begin{array}{l}\text { 最大荷息 } \\
P_{\mathrm{m}}(\mathrm{kN}) \\
\end{array}$ & $\begin{array}{c}\text { 曲(゙゚ヤング係数 } \\
\left(\mathrm{kN} / \mathrm{cm}^{2}\right)\end{array}$ & 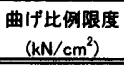 & 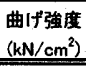 \\
\hline $\mathrm{X} 2 \mathrm{Y}_{6}$ & 2.7 & 720.4 & 3.3 & 6.6 \\
\hline $\mathrm{X} 3 \mathrm{Y}_{4}$ & 2.4 & 867.0 & 3.0 & 6.0 \\
\hline X3Y6 & 3.1 & 1027.9 & 3.9 & 7.8 \\
\hline $\mathrm{X} 4 \mathrm{\gamma 2}$ & 0.4 & 235.5 & 0.5 & 1.1 \\
\hline $\mathrm{X} 4 \mathrm{Y} 4$ & 1.5 & 750.5 & 2.1 & 4.2 \\
\hline $\mathrm{X} 4 \mathrm{Y} 6$ & 1.8 & 666.3 & 2.3 & 4.6 \\
\hline
\end{tabular}
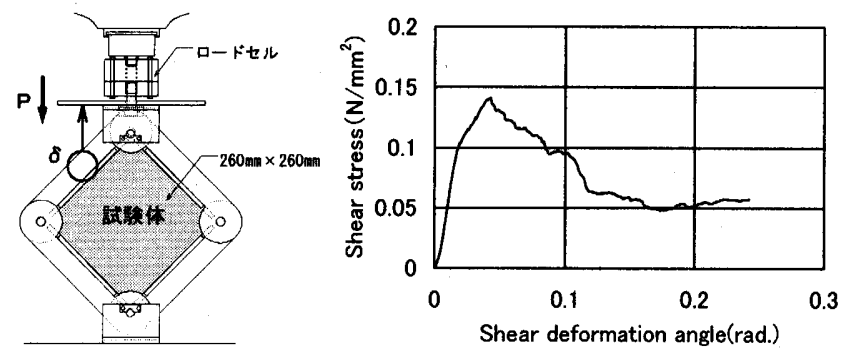

図 15 土壁要素実験 治具図 16 土壁 せん断応力度一せん断変形角関係

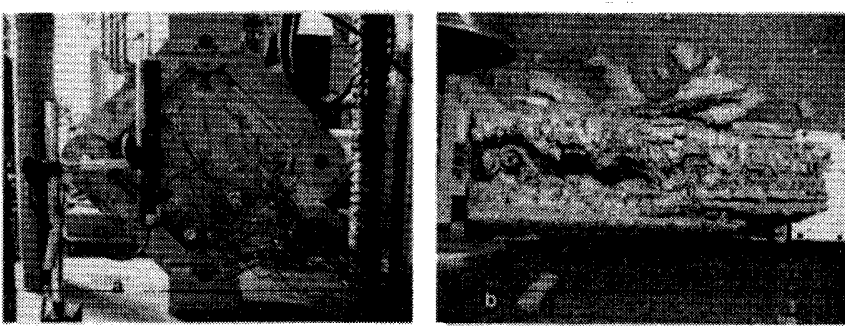

写真 5 土壁要素実験 


\section{6 対象住宅のカ学モデルによる解析}

実大静的水平加力実験の検証を解析的に行った。本稿の解析では 無開口壁（土壁）と垂壁付き独立柱の 2 要素から耐力を算出した。 土壁はせん断剛性から耐力を算出し ${ }^{18)}$ 、垂壁付き独立柱は既往の垂 壁理論 ${ }^{191}$ より土壁（垂壁）のせん断剛性と柱の曲げ剛性が直列接続 するとして算出した（図 17）。この 2 要素の荷重変形関係を建物全 体（桁行方向）について求めた。解析に用いた定数（ヤング係数・ 曲げ応力度・せん断応力度）は、材料実験の結果を基に、柱の曲げ 応力度について久点の低隇係数 20)を、土壁のせん断応力度につい ては木材の変動係数を参考にしてばらつきの低減係数 ${ }^{17}$ を乗じ仮 定した（表 5)。なお、治具設置のために除去した垂壁（図 2 参照） は耐力要素から除いた。解析における最大耐力は $81 \mathrm{kN}(1 / 45 \mathrm{rad}$. 時）となり、実験結果の $45 \mathrm{kN}$ の約 1.8 倍の値となった（図 18）。

さらに垂壁付き独立柱 (大黒柱、小黒柱)について比較を行った。 2.3 章 3）にて実験で得たひずみゲージの值から算出したせん断力と、 垂壁モデルから求めた解析值を比較した（図 19）。解析值は最大耐 力が大きく $0.03 \mathrm{rad}$. 前後で柱が折損したが、実験值では、解析值の 約 0.4 倍の耐力を実験の最大変形時まで保持した。なお、実験値の 変形角は柱頭の值を用いたが、途中から計測不能となっていた。

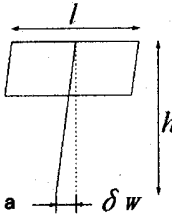

a) 夜形概念図

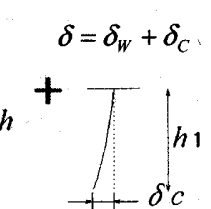

b) 荷重 - 変形関係

（垂壁付き独立柱）

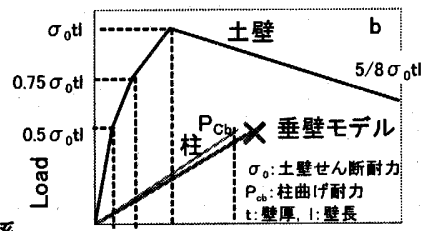

$0 \frac{h}{250} \frac{h}{120} \frac{h}{60} \delta_{c b} \quad$ Disp. $\frac{h}{15}$
表 5 解析に用いたヤング係数と応力度 $\%$

\begin{tabular}{|c|c|c|c|c|}
\hline \multirow[t]{2}{*}{. } & \multirow{2}{*}{$\begin{array}{c}\text { ヤング係数 }\left(\mathrm{kN} / \mathrm{cm}^{2}\right) \\
\text { 实験結果 }\end{array}$} & \multicolumn{3}{|c|}{ 㐫力度 $\left(\mathrm{kN} / \mathrm{cm}^{2}\right)$} \\
\hline & & 实験結果 & 低隇係数 & 筆出値 \\
\hline 柱(健全) & 812.0 & 5.8 & 0.45 (久点) & 2.61 \\
\hline 柱(少化) & 235.5 & 1.1 & 0.45 (欠点) & 0.49 \\
\hline 土㕸 (漆喰あり) & - & 0.014 & 0.8(ばらつき) & 0.011 \\
\hline 土壁 (漆㫰なし) & - & $0.007^{21)}$ & 0.8(ばらつき) & 0.006 \\
\hline
\end{tabular}

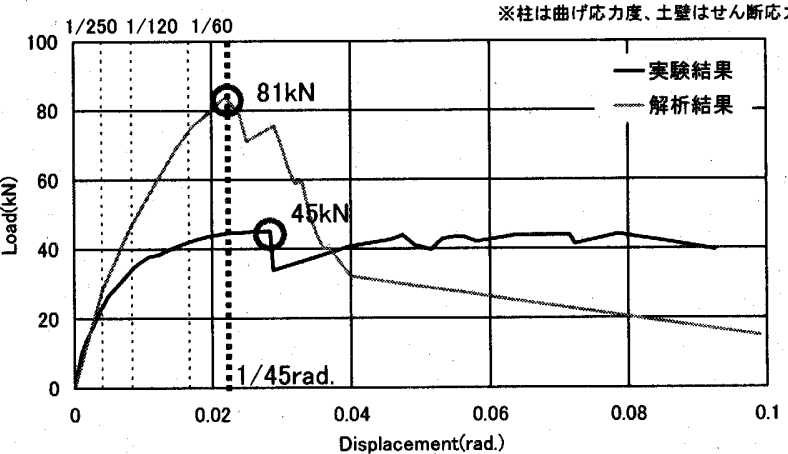

図 18 荷重一变形関係 現地実験の結果（図 9）と解析結果の比較

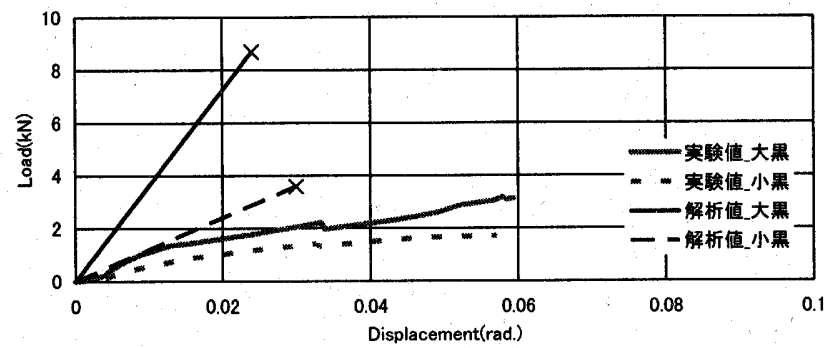

図 19 耐力要素（大黒柱・小黑柱）による実験值と解析値の比較

\section{3. 耐力要素の検証}

実験結果と解析結果の比較において住宅全体の最大耐力で約 1.8 倍の差が認められ、大黒柱・小黒柱の比較でも荷重一変形関係に差 が認められたことから、垂壁付き独立柱と接合部の構造性能を踏ま え、力学モデルの妥当性の検証を行った。

\section{1 垂壁付き独立柱}

無開口壁の少ない住宅において重要な水平耐力要素である垂壁付 き独立柱を対象として実物大実験を行い、実験結果から垂壁付き独 立柱の構造性能の定量的な評価と、力学モデルとの比較を行った ${ }^{22) 。 ~}$ 柱と差鴨居からなる軸組に土塗の垂壁を設け試験体を作成した。 仕口形状はほぞ差込栓と車知栓の差鴨居 2 種類合計 2 体とし、過去 水平加力実験を行った住宅 51,67.8) を基に設計して用いた（図 20）。 実験方法は、柱頭の水平変位で制御を行い、正負交番に水平に加力 を行った（図 21）。写真 6 に実験風景を示す。(詳細は既報 ${ }^{221)}$ )

\section{1) 実験結果}

復元力特性は各試験体とも正負非対称のスリップ型であった。破 壊時の耐力は込栓試験体 $4.5 \mathrm{kN}(+1 / 20 \mathrm{rad}$. 時) 、車知栓試験体 $4.2 \mathrm{kN}$ (-1/24rad.時)であり、差鴨居との接合部で柱に曲げ破壊が生じた。 柱の折損発生時まで剛性はほぼ一定であった。本要素実験に用いた 垂壁付き独立柱 2 体では最大耐力、剛性に顕著な違いはなかったが、 破壊時の変形角に差が認められた。

\section{2）解析結果との比較}

既往の理論 ${ }^{191}$ を用いて解析を行い、実物大垂壁実験の結果と比較 すると、剛性は実験結果（1/30 rad.時の割線剛性）の約 2 倍、最大 耐力は $6.0 \mathrm{kN}$ となり実験結果の約 1.3 倍となった（図 22）。
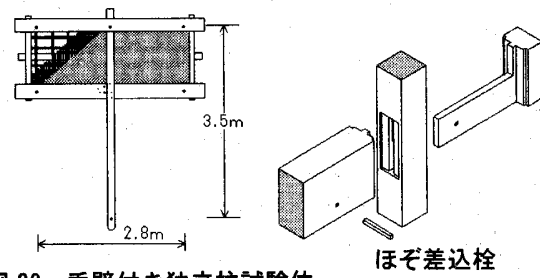

図 20 垂壁付き独立柱試験体
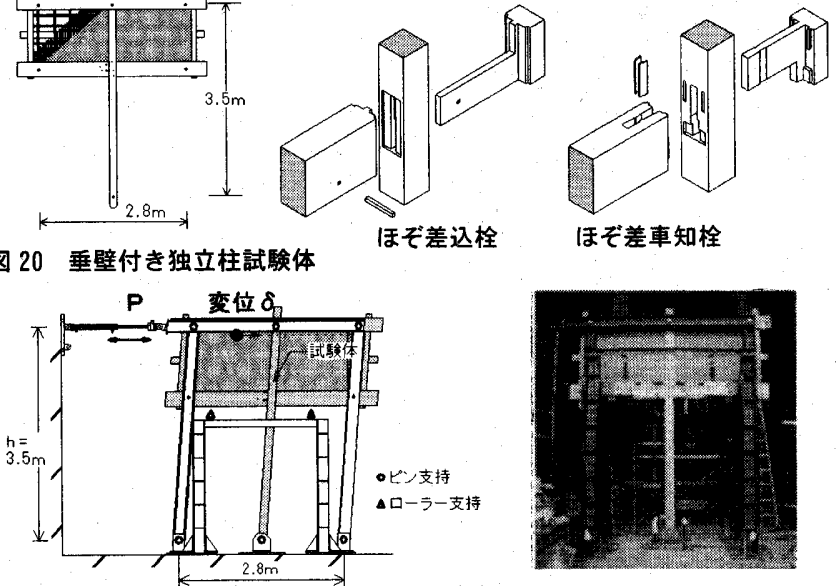

図 21 垂壁実験 实験方法
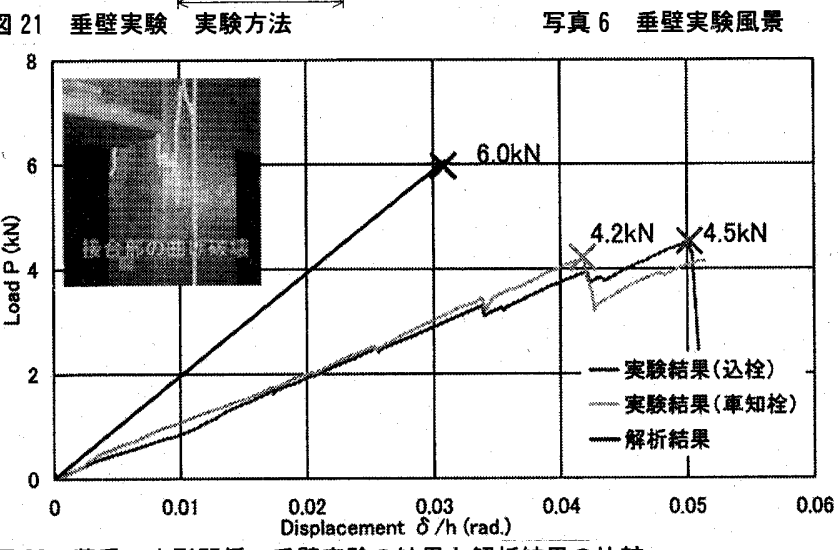

図 22 荷重一变形関係 垂壁実験の結果と解析結果の比較 


\section{2 接合部性能}

3.1 章で認められたように、垂壁付き独立柱等の破壊は接合部位 置での発生が多く見られる。本住宅の現地実験では加力による柱接 合部の破壊は認められなかったが、接合部の構造性能の検証として 実物大接合部試験体を対象とした静的水平加力実験を行った ${ }^{23 \%}$ 。

\section{1) 実験概要}

実物大の柱・横架材接合部の試験体を作成した。仕口形状は近世 以降農家型住宅によく用いられる差鴨居、貫と長押からなる一般的 な横架材、さらに長押が構造材であった古代の頃のものを参考に作 成した矩形の長押の 3 種類を設計した（図 23）。樹種はアカマッと し、差鴨居の木栓には堅木 (ケヤキ) を用いた。実験方法は垂壁実 験に準ずる (図 21 参照)。(詳細は既報 $\left.{ }^{23 〉}\right)$

\section{2）実験結果}

復元力特性は 3 種ともスリップ型であった。差鴨居は正負非対称、 貫十長押、矩形長押の 2 体は正負対称の履歴を示した。各実験結果 の包絡線を図 24 に示す。1/30 rad.時の割線剛性は 18〜20kN/rad.と いう值が得られた。差鴨居試験体は約 0.017 rad. 付近で剛性の低下が 認められたが、目視からは多少めり込みが生じた程度であった（図 24a)。柱の変形が大きく、1/25 rad.まで加力を行っても各試験体とも 接合部の破損住められなかうた。

\section{3）モデルへの適用}

この実験結果の剛性をもとに各試験体の接合部の回転剛性を算出 した。回転剛性は水平剛性に換算し、次式を用いて算出した。 $\frac{1}{K}=\frac{1}{k_{c}}+\frac{1}{k_{j}} （ K$ : 実験結果 $\frac{P}{\delta}[\mathrm{kN} / \mathrm{mm}] \quad k_{c}$ :柱の曲げ剛性 $k_{j}$ : 接 合部の回転剛性)

接合部の回転剛性は 3 種の平均值約 $23.5 \mathrm{kN} / \mathrm{rad}$.となり、柱の曲げ 剛性と比較すると約 $1 / 4$ 倍の差があることがわかる。この算出結果 から柱・差鴨居接合部は回転剛性約 $20 \mathrm{kN} / \mathrm{rad}$.であるとして、垂壁 付き独立柱の構造性能を再検討した。
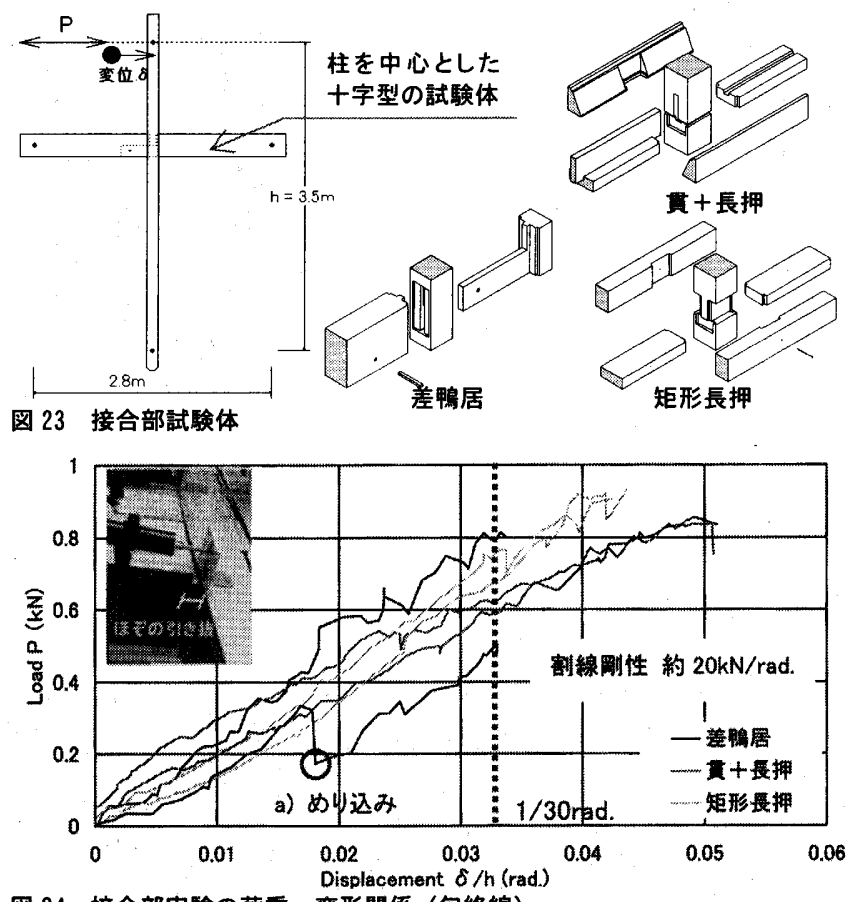

図 24 接合部実験の荷重一变形関係（包絡線）

\section{4. カ学モデルの修正}

垂壁付き独立柱について 3.1 章で検証を行つたが、実験結果と解 析結果とで差が認められた。その差の原因と考えられる接合部の影 響に着目して、要素実験の結果を踏まえて力学モデルに修正を行い、 伝統的木造住宅の構造性能評価の精度の向上を目指した。

\section{1 断面欠損の考慮}

既往の垂壁モデルについて、柱接合部での断面欠損を以下の 2 点 について考慮しモデルの修正を行った（図 25）。

1) 柱の曲げ耐力

柱接合部には差鴨居等横架材との仕口による断面欠損があり、柱 の曲げ耐力に影響を及ぼすと考え、断面欠損を考慮して断面係数を 求め柱の曲げ耐力を算出した。断面欠損部分には胴付等は含まず、 ほぞ穴のみを対象とした（実測調查からほぞ穴幅は $3 \mathrm{~cm}$ とした）。 $Z=\frac{(b-3) h^{3} / 12}{h / 2}$ ( $Z$ : 断面係数 $b$ :柱断面の幅 $h$ :柱断面の奥行 $)$

\section{2）柱の曲げ剛性}

柱の剛性を算出する際、柱上部（垂壁側）を固定端と仮定して計 算を行うが、この際に接合部の断面欠損によって柱が変断面である と考えた。各断面の剛性の和から柱の曲げ剛性を算出した。変断面 となる長さは差鴨居のせいの寸法と同一とし、各剛性は水平剛性に 換算して計算を行った。

$K_{c b}=3 E_{c} I \cdot \frac{l}{\left(l-l^{\prime}\right)^{3}}+3 E_{c} I^{\prime} \cdot \frac{l}{\left(3 l^{2}-3 l l^{\prime}+l^{\prime 2}\right)^{\prime \prime}}$

$\left(K_{c b}\right.$ : 柱の曲げ剛性 $E_{c}$ :柱のヤング倸数 $I$ :断面 2 次モーメント $I^{\prime}$ :変断面部分の断面 2 次モーメント $l$ :柱長さ $l^{\prime}$ :変断面長さ)

\section{2 接合部性能の付加}

3.2 章の接合部実物大実験の結果を基に垂壁モデルに接合部の回 転剛性を加味した。垂壁付き独立柱に水平荷重がかかった際に、柱 と横架材の接合部位置にめり込み等による回転剛性が働いていると 考えられる（図 25）。接合部は土壁によって拘束されると考え、各 剛性を水平剛性に換算して土壁の持つせん断剛性を算出した。

$K_{w j}=k_{w}+k_{j} \quad （ K_{w j}$ : 接合部性能を付加した土壁のせん断剛性 $k_{w}$ : 土壁のせん断剛性 $k_{j}$ :接合部の回転剛性）

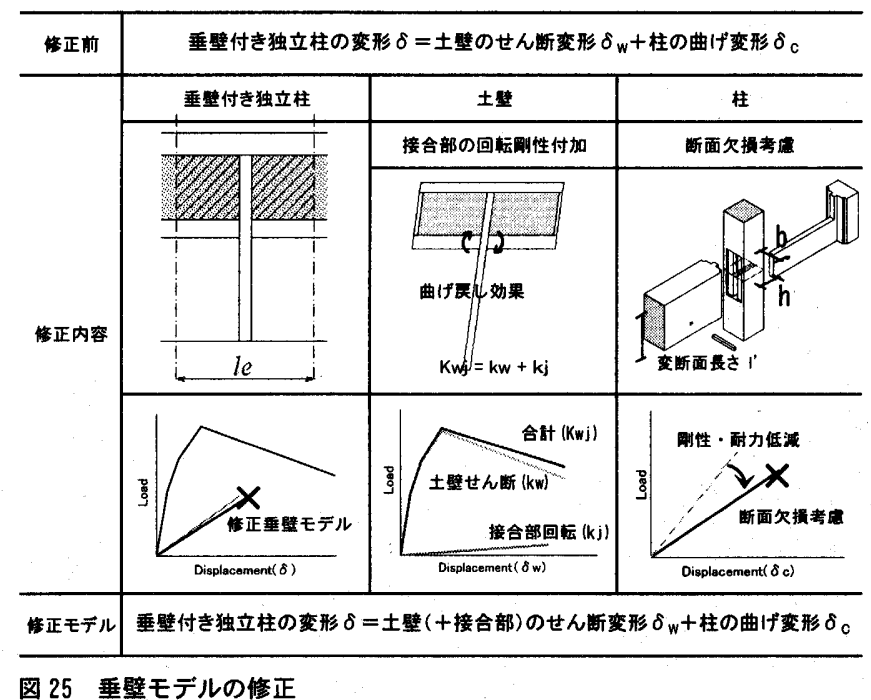




\section{3 修正モデルの検証}

断面欠損のみ考慮して解析を行うと最大耐力 $4.25 \mathrm{kN}$ 、剛性 $98 \mathrm{kN} / \mathrm{rad}$.となった。また、接合部の回転剛性のみを考慮した場合、 最大耐力 $6.05 \mathrm{kN}$ 、剛性 $221 \mathrm{kN} / \mathrm{rad}$.となった。部材の断面欠損・接 合部の回転剛性を考慮して修正した力学モデルを用いた解析結果は 最大耐力 $4.25 \mathrm{kN}$ 、剛性 $103 \mathrm{kN} / \mathrm{rad}$.となった（図 26）。実物大垂壁実 験では破壊耐力 4.2 4.5kN、1/30 rad.時の割線剛性 97〜 $101 \mathrm{kN} / \mathrm{rad}$. を示しており、既往の垂壁理論は接合部性能を考慮することで、実 験結果と比較的よく一致するといえる。また、2.6 章と同様に、現 地実験のひずみの值から算出した值と修正垂壁モデルによる解析値 の比較を大黒柱・小黒柱について行った（図 27）。その結果、差は 若干縮まったが一致は認められなかった。解析値で柱が折損すると なっても、実際は折損せず耐力を保持し続けることが認められた。

\section{4 修正モデルによる住宅の解析的検証}

静的水平加力実験を行った住宅を対象として修正力学モデルを用 いて構造性能の評価を行った。解析の結果、算出した最大耐力は実 験結果の約 1.6 倍である $75 \mathrm{kN}(1 / 35 \mathrm{rad}$.時) となった(図 29 に後述)。 初期剛性はある程度一致するが、初期剛性以降の復元力特性が異な る。部材の断面欠損等を考慮しても解析結果の值が実験結果より大 きく、過大評価の傾向を示す。

\section{5 既往の研究対象住宅による修正モデルの検証}

修正モデルによる解析結果と実験結果との比較において、いまだ 1.6 倍もの差が生じているが、この差が本住宅固有の問題によるも のであるか、一般的な問題によるものであるのか明らかでない。そ こで、杉山らの研究（Y 邸）と筆者らの行った既往の研究（H 邸、 $S$ 邸）のデータを用いて修正解析モデルの検証を試みた（表 6)。

$S$ 邸（桁行方向加力）の解析結果を図 28 に示す。 $S$ 邸の実験では 破壞まで加力を行わなかったため最大耐力での比較は行えないが、 初期剛性は比較的近い值を示している。Y 邸では初期剛性はよく一 致し、解析結果の最大耐力は実験結果の 1.13 倍となった。 $\mathrm{H}$ 邸では 解析結果が実験結果よりも小さい值を示した。初期剛性では解析結 果が実験結果の 0.54 倍となり、最大耐力では 0.84 倍となった。こ の検証より、H 新では不一致であったが、その他 2 棟と本住宅では 解析結果と実験結果の初期剛性に一致が認められたことから、修正 モデルで初期剛性までは比較的評価できていると考えられる。その 後の最大耐力までの復元力特性についてはY 邸では比較的一致が認 められることから、本住宅で最大酎力 1.6 倍の差となったことは本 住宅固有の問題による可能性が考えられる。

\section{6 劣化部材の検討}

以上を踏まえ、本住宅の実態調査の結果に基づいて、劣化等によ る耐力の低減を検討した。なお、本実験では主要な 3 構面が等変位 となるように加力を行ったので、水平構面剛性については考慮しな い。劣化の進行が著しい部材は耐力要素として有効ではなくなると 考え、加力実験前に行った実態調查を基に詳細に検討を行った。蟻 害や雨漏りによって柱頭、柱脚、土壁等に劣化が認められ（図 2 参 照)、これらの部材を耐力要素から除外した。劣化部材を耐力要素か ら除外して解析を行った結果、最大耐力は $69 \mathrm{kN}$ と低隇された（図 29)。最大耐力時の変形角は実験結果と一致している。約 $1 / 200 \mathrm{rad}$ までは実験結果と近似した包絡線を描いているが、実験結果より解 析結果の方が、最大耐力が大きくなる傾向が認められる。

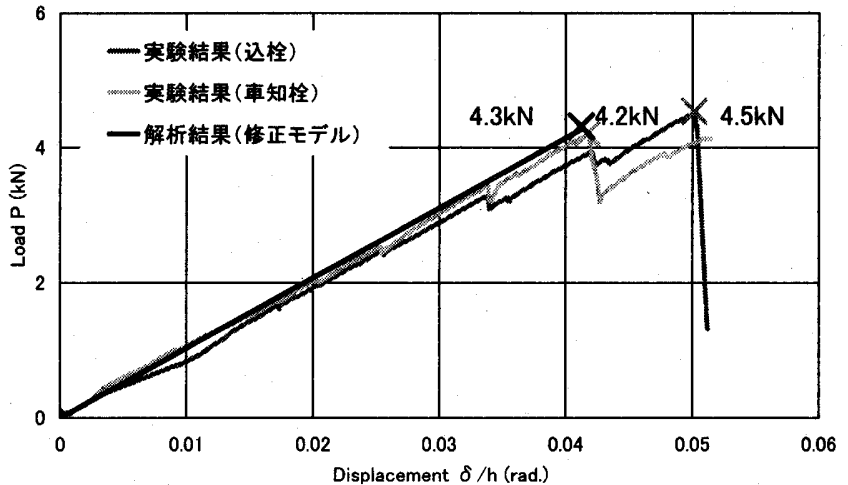

図 26 荷重一変形関係 重壁実験の結果と修正モデルによる解析結果の比較

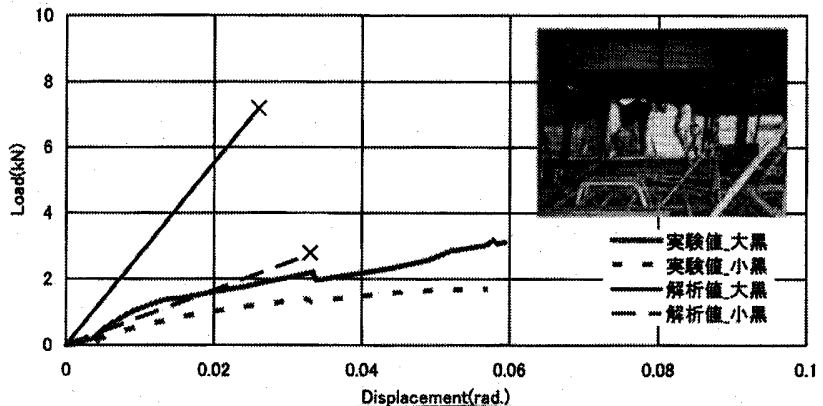

図 27 修正モデルでの耐カ要素（大黒柱と小黒柱）の比較

表 6 既往の研究対象住宅による解析モデルの検証

\begin{tabular}{|c|c|c|c|c|c|c|c|c|}
\hline \multirow{2}{*}{\multicolumn{2}{|c|}{ 建物名称（出典） }} & \multirow{3}{*}{ 加力方向 } & \multicolumn{3}{|c|}{ 㝢験結果 } & \multicolumn{2}{|c|}{ 解析結果 } & \multirow{3}{*}{ 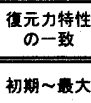 } \\
\hline & & & \multirow{2}{*}{$\begin{array}{l}P_{\text {mAX }} \\
69.6\end{array}$} & \multirow{2}{*}{$\frac{\theta}{0.033}$} & \multirow{2}{*}{$\frac{\mathrm{Ci}}{0.22}$} & \multirow{2}{*}{$\begin{array}{l}P_{\max } \\
78.5\end{array}$} & \multirow{2}{*}{$\frac{\theta}{0.025}$} & \\
\hline Y期 & 2 & & & & & & & \\
\hline 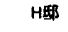 & 5,6 & 析行 & 69.0 & 0.032 & 0.14 & 57.8 & 0.038 & - \\
\hline \multirow{2}{*}{ s毁 } & \multirow{2}{*}{8} & 粱的 & $44.3^{* 1}$ & 0.011 & 0.18 & 115.9 & 0.038 & 初期 \\
\hline & & 析行 & $51.2^{* 1}$ & 0.015 & 0.21 & 83.0 & 0.031 & 初期 \\
\hline
\end{tabular}

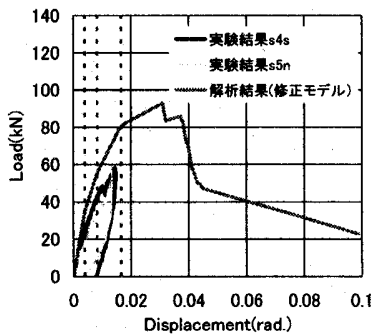

a) 荷重一変形関係

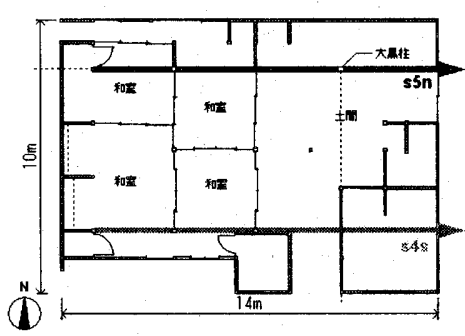

b）載荷方法 (平面図)
图 28 修正モデルでの住宅解析例 ( $S$ 邱)

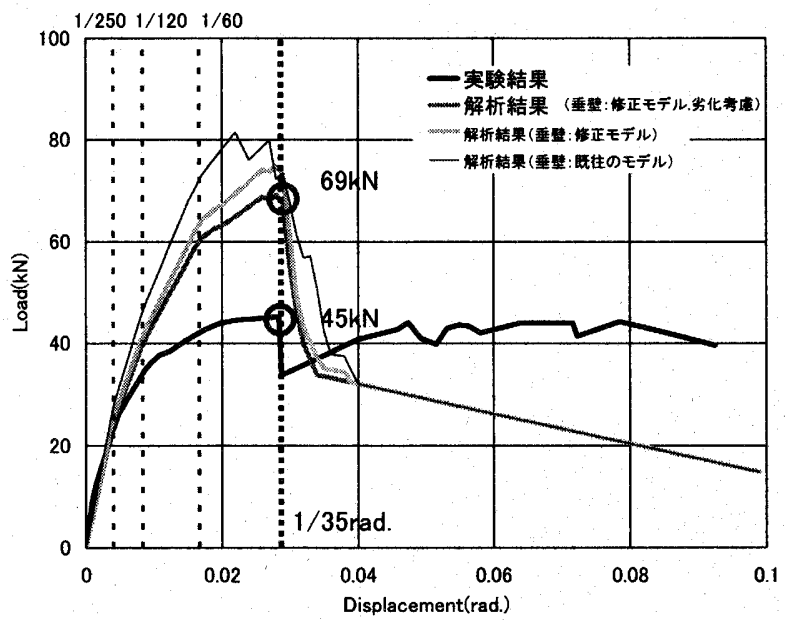

図 29 荷重一变形関係 現地実験の結果（図 9) と修正解析結果の比較 


\section{5. 考察}

農家型の伝統的木造住宅を対象とした現地での静的水平加力実験 を行った。対象住宅は山口県の農家として一般的な特徽をもつ。本 住宅の固有振動数は $3.5 \sim 3.9 \mathrm{~Hz}$ 、減衰定数は $2.6 \sim 2.9 \%$ であった。 既往の研究の対象住宅より固有振動数が高い。静的水平加力実験の 結果から本住宅の最大耐力は $45 \mathrm{kN}$ であり、既往の実験的研究によ る農家型住宅の平均値より約 3 割低い值であった。層せん断力係数 で評価すると本住宅は 0.20 であり、既往の研究の住宅と同等程度の 耐力を保持していると考えられる。また、微動測定で得た固有振動 数を基に初期剛性を算出したところ、実験結果より高い值を示した。 水平耐力要素の検証として、垂壁付き独立柱の実物大実験を行っ た。その結果、1/24〜1/20 rad.時に垂壁下の接合部位置で柱が曲げ破 壊を生じ、最大耐力を得た。接合部の実物大実験では、本実験で対 象とした仕口形状では剛性に差があまり認められなかった。これら の実物大実験の結果を基に、既往の垂壁モデルに接合部の断面欠損、 回転剛性を考慮することで、実物大垂壁実験の結果と解析結果は比 較的よく一致した。

以上を踏まえて現地実験について解析的に検証を行った。修正力 学モデルを用い、更に住宅の実態調查の結果から劣化等を考慮して 解析を行った。初期剛性と考えられる約 $1 / 200 \mathrm{rad}$.までは実験結果と 解析結果は比較的よく一致したが、それ以降は実験結果の剛性の低 下が大きく、値に差が生じた。破壊時の変形角はよく一致している。 既往の研究 ${ }^{6)}$ でも $1 / 60 \mathrm{rad}$.以降、実験結果と解析結果の一致は難し く、劣化や水平構面剛性等を考慮する必要があると指摘されている。 4.5 章の検証では、本稿の解析モデルは、初期剛性から最大耐力ま では比較的一致が認められる。本住宅で初期剛性後の復元力特性の 不一致は、本住宅固有の問題の可能性もある。

さらに、考慮できていない不確定な要素として、耐力要素として 解析に用いた垂壁付き独立柱が挙げられる。2.3 章 2) で示したよう に変形性状に差が認められた。また、実験から得た大黒柱と小黒柱 の復元力特性は、大変形領域でも柱は折れず耐力を保持した。要素 実験では垂壁付き独立柱はよく評価されているが、住宅の中で用い られた際は施工精度や少化にも影響を受けるため、挙動を必ずしも 把握しきれていない。実験から得た大黒柱・小黒柱の復元力特性は、 住宅の現地実験結果で最大耐力を得た後ほとんど耐力が低下せず変 形が進行した点と同様の傾向が認められ、この性能を適切に評価す ることで実験値と解析值の差が隇少すると考えられる。本稿では耐 力要素として無開口壁、垂壁付き独立柱の 2 要素のみ検討したが、 壁を含まない開放的軸組の効果等も考慮する必要がある。上述の垂 壁付き独立柱の構造性能と併せて今後の検討課題としたい。

\section{6. 結論}

本研究から得られた結論は以下のとおりである。

1）本住宅は約 1/200 rad.以降剛性が徐々に低下し、1/35rad.で最大耐 力 $45 \mathrm{kN}$ を得た。最大軵力以降、耐力低下はほとんどなく変形のみ 進行した。最大耐力から算出した層せん断力係数は 0.20 であり、既 往の研究との比較から農家型住宅として妥当な値を示している。

2) 既往の垂壁モデルについて、垂壁付き独立柱の実物大要素実験の 結果を基に、部材の断面欠損や接合部の回転剛性を考慮して修正を 行った。接合部性能を考慮することで垂壁付き独立柱の構造性能は、
修正前のモデルによる解析值より最大耐力が約 3 割、剛性が約 5 割 低減され、実物大要素実験の結果とよく一致した。

3）現地実験について、修正した力学モデルを用いて解析的に検証を 行った。荷重一変形関係は、約 1/200 rad.までは実験結果と解析結果 が比較的よく一致したが、1/200 rad.以降の復元力特性に差が生じた。 最大耐力を得る変形角は実験結果と解析結果で一致が認められた。 本解析モデルの検証では、最大耐力までは比較的一致が認められ、 本住宅における不一致は住宅の持つ固有の問題もあると考えられる。 主要な構造要素である垂壁付き独立柱の変形性状・復元力特性の力 学モデルとの相違点や、開放的軸組の耐力などの不確定な要素につ いて、今後検討を行う必要がある。

謝辞 本研究を行うにあたって、ご指導頂いた建築研究所の河合直 人先生、伝統的木造住宅の現地実験を行うにあたって多大なご協力 を頂いた山口大学の中園畺人先生、岩田真次氏、盆子原和也氏、金 子棟梁、垂壁実物大実験を行った降幡建築設計事務所の藤原稲子氏、 その他実験等にご協力頂いた多くの方々に心より謝意を表します。 参考文献

1) 国土交通省住宅局建築指導課：木造住宅の耐震診断と補強方法 木造住宅 の耐震精密診断之補強方法（改訂版），財団法人日本建築防災協会, 2004.7

2）杉山英男ほか 3 名: 江戸時代に建築された農家の水平加力試験の結果, 日 本建築学会構造系論文報告集, 第 360 号, pp.23-30, 1986.2

3) 坂本 功, 河合直人, 山下伸夫ほか 2 名: 伝統的木造住宅の水平加力なら びに振動実験, 日本建築学会大会学術講演梗概集, C-1, pp.1227-1232, 1985.10

4) 福本和正ほか 2 名: 在来構法賟惪き木造住宅の静的水平加力実験加求め た水平耐力と壁・柱の分担率, 日本建築学会大会学術講演梗概集, C-1, pp.135-136, 2000.9

5) 森川昌志, 岩田真次, 近藤 哲ほか 3 名 : 伝統的木造住宅の水平耐力に関 する実験的研究, 日本建築学会大会学術講演梗概集, C-1, pp.147-152, 2001.9

6) Kaori FUJITA, Tetsu KONDO, et. al: On-Site Lateral Loading Test of a Traditional Timber House in Japan, Journal of Asian Architecture and Building Engineering, vol.3, no.1, pp.41-46, 2004.5

7) 呉若威, 宮本俊輔, 宮澤健二:伝統木造住宅の構造性能に関する研究, 日本 建築学会構造工学論文集, vol.49B, pp.45-52, 2003.4

8) 福本和正，西澤英和，藤田香織ほか 4 名：現地試験による伝統的木造民家 の構造性能に関する実験的研究 滋賀県甲賀町の茅惪民家, 日本建築学会 大会学術講演梗概集, C-1, pp.429-437, 2003.9

9) 長谷川翠，岡村雅克ほか 5 名: 徳島県に建つ古民家の構造詳細調查及び実 大実験, 日本建築学会大会学術講演梗概集, C-1, pp.51-54, 2004.8

10）軽部正彦ほか 5 名: 明治 20 年に建築された伝統的木造住宅の調査, 日本 建築学会大会学術講演梗概集, C-1, pp.83-84, 2004.8

11）鈴木祥之：伝統的構法木造建物の耐震性能評価実験，『木』の力を探る一 構造篇一一告䢖築の構造実験・七賢人連続発表会一資料集, pp.63-72, 2005.5

12）出水文二, 佐藤弘美, 松田昌洋ほか 4 名: 山口県の伝統的木造住宅の実大 水平加力実験, 日本建築学会大会学術譜演梗概集, C-1, pp.475-480, 2005.9

13) 山口県教育委員会: 山口県の民家 昭和 47 年度民家緊急調查報告, 1974.3

14）堀江 亨 : 柱・梁の配置からみた近世農家の軸組架構の多様性 日本の 伝統的民家の架構法に関する系統的研究 その 1, 日本建筑学会計画系論 文集, 第 538 号, pp.109-116, 2002.12

15）安藤邦廣, 乾 尚彦, 山下浩一, 井上勝徳 : 住宅構法の地域特性 重要 文化財民家修理工事報告書による解析・その 2 , 日本建築学会大会学術諎 演梗概集，pp.909-910，1981.9

16）小坪清真：入門建設振動学, 森北出版, 1996.1

17) 中塚佶, 濱原正行, 村上雅英, 飯島泰男: I一ス建築構造材料学, 朝 倉書店, 2004.4

18）河合直人：土叙壁の設計，建築技術, pp.118-121, 1995.11

19）前川秀幸, 河合直人, 内田昭人：伝統的木造建築物の振動特性 その 9, 日 本建築学会大会学術講演梗概集, C-1, pp.145-146, 2000.9

20) 日本建築学会: 木構造設計基淮 -同解説, 社団法人日本建築学会, 1973.4

21）鈴木祥之, 中治弘行 : 木造住宅士塗り壁の実大実験による耐震性能の再検 討, 日本建築学会構造系論文報告集, 第 515 号,pp.115-122, 1999.1

22）佐藤弘美, 藤原稲子, 藤田香織 : 差鴨居と垂壁の構造性能に関する実験的 研究，日本建築学会大会学術講演梗概集, C-1, pp.9-10,2004.8

23) 佐藤弘美, 藤原稲子, 藤田香織: 長押の形状の変遷と構造性能に関する実 験的研究, 日本建築学会大会学術講演梗概集, C-1, pp.413-414, 2003.9 